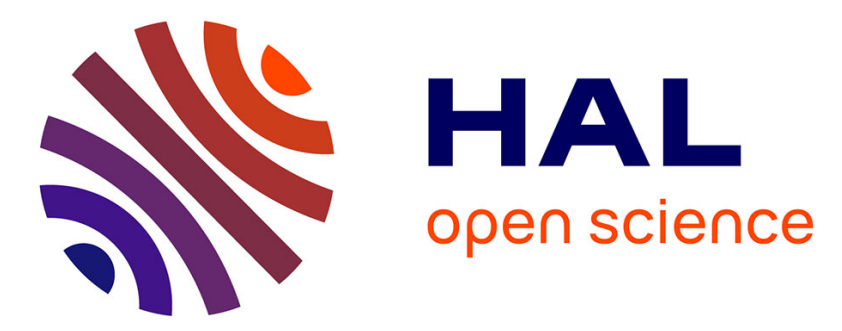

\title{
Restoring Brazilian savanna ground layer vegetation by topsoil and hay transfer
}

\author{
Natashi A. Lima Pilon, Elise Buisson, Giselda Durigan
}

\section{To cite this version:}

Natashi A. Lima Pilon, Elise Buisson, Giselda Durigan. Restoring Brazilian savanna ground layer vegetation by topsoil and hay transfer. Restoration Ecology, 2018, 26 (1), pp.73-81. 10.1111/rec.12534 . hal-01927858

\section{HAL Id: hal-01927858 \\ https://hal.science/hal-01927858}

Submitted on 16 Jan 2020

HAL is a multi-disciplinary open access archive for the deposit and dissemination of scientific research documents, whether they are published or not. The documents may come from teaching and research institutions in France or abroad, or from public or private research centers.
L'archive ouverte pluridisciplinaire HAL, est destinée au dépôt et à la diffusion de documents scientifiques de niveau recherche, publiés ou non, émanant des établissements d'enseignement et de recherche français ou étrangers, des laboratoires publics ou privés. 


\title{
Restoring Brazilian savanna ground layer vegetation by topsoil and hay transfer
}

\author{
Natashi A. Lima Pilon \\ Elise Buisson \\ Giselda Durigan \\ First published: 10 May 2017 \\ https://doi.org/10.1111/rec.12534 \\ Cited by: $\underline{9}$
}

Author contributions: NALP, GD conceived and designed the research and performed the experiments; NALP, EB analyzed the data; GD, EB contributed rearrangements and analysis tools; NALP, GB, EB wrote and edited the manuscript.

Coordinating Editor: Gerhard Overbeck

\begin{abstract}
Tropical grassy biomes have been widely neglected for conservation and, after unplanned land use conversion, ecological restoration becomes urgent. The majority of interventions have been based on the misapplication of forest restoration techniques, because there are no validated techniques to restore the species-rich ground layer. In search for innovative techniques to restore the herbaceous layer of the cerrado vegetation, we carried out an experiment based upon topsoil and hay transfer, in the state of São Paulo, Brazil. The restoration treatments were: (1) transfer of topsoil collected at the end of the dry season; (2) topsoil collected at the end of the rainy season; (3) transfer of hay collected at the end of the dry season; (4) topsoil + hay collected at the end of the dry season; and (5) control. We used an old-growth grassland as source of material and as reference ecosystem to assess the efficacy of the restoration techniques applied to an area severely degraded after invasion by African grasses. After 211 days, hay transfer apparently inhibited germination and did not contribute to grassland vegetation recovery. Topsoil transfer, however, was effective at reintroducing herbaceous plants, including target species. The season of topsoil collection mattered: material collected at the end of the rainy season provided better results in terms of density and richness of the restored community than that from the dry season. The remaining challenge is to find sources of topsoil not invaded by exotic grasses in large enough amounts to support restoration initiatives without jeopardizing the source ecosystems.
\end{abstract}

\section{Implications for Practice}

- Topsoil transfer can help to recover the herbaceous layer of cerrado grassland.

- Even though less destructive than topsoil removal for the donor site, hay transposition is not an effective technique to restore cerrado grasslands.

- Shrubs and subshrubs do not return using topsoil transfer, complementary techniques are therefore required to recover these species.

- Collecting cerrado topsoil just after seed dispersal of most grasses, at the end of the rainy season, ensures a topsoil richer in propagules.

\section{Introduction}


As native ecosystems worldwide become degraded due to the expansion of human activities (e.g. intensive agriculture, industry, urban sprawl, etc.), the demand for ecological restoration also increases. Successful restoration, however, depends on adequate situation-specific techniques that are not always available. Effective techniques for restoring tropical savannas are largely lacking, especially when it comes to recovering herbaceous plant communities for which techniques focused on tree planting are not adequate (Veldman et al. 2015b). In subtropical and temperate climates, restoration of the herbaceous layer of savanna ecosystems has been studied. For example, techniques involving the reestablishment of fire regimes and introducing native species (e.g. direct seeding or outplanting) have been applied in longleaf pine savannas and oak savannas in the United States (Maloney 1997; Van Lear et al. 2005; Walker \& Silletti 2006; Harrington \& Kathol 2009).

The Brazilian cerrado is the most biodiverse savanna of the world and is now in a critical state of degradation (Klink \& Machado 2005), with large areas in urgent need of restoration. The cerrado vegetation comprises a mosaic of vegetation types ranging from grasslands to woodlands (Ribeiro \& Walter 2008). Except for the latter, the ground layer, composed by a high diversity of grasses, forbs, and sedges, as well as some subshrubs, is an essential component of the cerrado vegetation. Large parts of the endemic fauna and some relevant ecosystem services, such as pollination, carbon storage, erosion control, water protection, depend on the ground layer (Veldman et al. 2015a).

Techniques that involve planting seedlings, nucleation, or natural regeneration by resprouting have been proposed as ways to restore shrub and tree populations in the cerrado (Durigan et al. 1997, 1998; Durigan 2003; Pilon \& Durigan 2013; Corrêa et al. 2015). However, in general, the majority of interventions have been based on the misapplication of forest restoration techniques (Durigan \& Engel 2012). By planting only trees on the basis of secondary succession (Kageyama \& Gandara 2000; Rodrigues et al. 2009), cerrado restoration outcomes have been ecosystems that roughly resemble the forest type of cerrado vegetation, the "cerradão," whereas restoration of the herbaceous layer has been largely neglected. Therefore, one of the major issues in restoring the cerrado is to restore the herbaceous plant communities that characterize these vegetation types. Because these plants are neither commercially available nor do we have the knowledge or technology to propagate them, restoration of these communities is still challenging.

Recent studies using topsoil transfer (i.e. propagule transfer either via intact turves, fragmented turves, or bulk topsoil) and hay transfer (i.e. diaspore transfer with plant material) have shown efficient ways to restore herbaceous plant communities under temperate climate (Bossuyt \& Hermy 2003; Hölzel \& Otte 2003; Vécrin \& Muller 2003; Rasran et al. 2007; Kiehl et al. 2010; Klimkowska et al. 2010; Burmeier et al. 2011; Coiffait-Gombault et al. 2011, 2012; Jaunatre et al. 2012). These techniques allow propagules to reach the sites to be restored, overcoming long-distance dispersal limitation, and thus accelerating the succession processes (Kiehl \& Wagner 2006; Kiehl \& Pfadenhauer 2007). Not only does topsoil transfer allow the transfer of seeds, it also allows the transfer of organic matter, microorganisms, such as mycorrhizal fungi, as well as nutrients contained in the native soil at amounts adequate for the restoration of the associated native plant community. On the other hand, hay transfer allows the transfer of many of the plant species contained in these species-rich temperate grasslands in an economically viable way compared to other techniques. The studies carried out on the use of hay transfer to overcome dispersal limitation in fragmented landscapes have shown that it can be used in a wide variety of ecosystems (e.g. dry grasslands, wet meadows, bogs, and steppes) (Kiehl 2010). 
While these two techniques (i.e. topsoil and hay transfer) have been tested in various grassland types in temperate climates, we found only a few studies from the tropical grassy biomes (Le Stradic et al. 2014 for hay transfer and Ferreira et al. 2015, Le Stradic et al. 2015 for topsoil translocation). In this context, the present study was designed to provide insights on the following basic questions regarding restoration of cerrado old-growth grasslands (sensu Veldman et al. 2015c): (1) can topsoil or hay transfer provide the recovery of the floristic composition and the proportion of life forms in reference ecosystems? (2) what is the best season for collecting topsoil in the reference ecosystem?

To answer these questions, we carried out an experiment comparing the plant communities created using these two techniques of transfer with each other and with that of the reference ecosystem from which the topsoil and hay had been taken.

\section{Methods}

\section{Study Sites}

The study was conducted in two conservation units: (1) Santa Bárbara Ecological Station (SBES; reference old-growth grassland where the topsoil and hay were collected) and (2) Assis State Forest (ASF; degraded ecosystem where the restoration experiment was set up), both located in the cerrado region of Brazil, in the state of São Paulo. SBES (22 $46^{\prime} 41^{\prime \prime} \mathrm{S}$ and $49^{\circ} 16^{\prime} 10^{\prime \prime} \mathrm{W}$ ) is located in the municipality of Águas de Santa Bárbara, where climate is classified as Cfa following the Köppen system (subtropical humid with hot summer) (Alvares et al. 2013). Mean temperature of the coldest 2 months is $18^{\circ} \mathrm{C}$ and that of the hottest 2 months is over $22^{\circ} \mathrm{C}$, with annual precipitation ranging from 1,000 and $1,300 \mathrm{~mm}$, concentrated in the summer (Alvares et al. 2013). The soil is classified as red latossol with a sandy texture. SBES presents different cerrado physionomies and grasslands cover 435 ha (Melo \& Durigan 2011). ASF $\left(22^{\circ} 33^{\prime} 10^{\prime \prime}\right.$ S and 50 $\left.24^{\prime} 05^{\prime \prime} \mathrm{W}\right)$ is located in the municipality of Assis, under the same climate and same soil type, classified as red latossol, here characterized by high acidity, low water holding capacity, low fertility, and high aluminum saturation (Durigan et al. 2010).

The restoration experiment was established at ASF in an area where the natural vegetation (cerrado sensu stricto) had been suppressed in the 1960s, and where the exotic invasive grass Urochloa decumbens (Stapf) R.D. Webster now has fully replaced the ground layer of native vegetation. There is no evidence of native vegetation recovery. Experimental plots were established in a $20 \times 50 \mathrm{~m}$ area that was scraped using a hydraulic leveling blade attached to a tractor. Scraping removed the entire aboveground biomass of existing vegetation and topsoil containing superficial roots and seed bank of invasive grasses and of any other species. In order to avoid edge effects, plots were not placed within $5 \mathrm{~m}$ of the border of the scraped area.

\section{Experimental Design}

We sampled five $50 \times 100 \mathrm{~cm}$ plots randomly established in the donor site (SBES) to assess how similar would be the communities obtained by the restoration techniques to the reference ecosystem in terms of species composition and proportions of life forms. Twenty-five $50 \times 100 \mathrm{~cm}\left(0.5 \mathrm{~m}^{2}\right)$ plots were installed in the scraped area, with five replicates for each of the five treatments in a completely randomized design. Each plot was delimited by wood 
planks ( $8 \mathrm{~cm}$ aboveground) to avoid any contamination or loss of material via run-off during exceptional rainfall events.

The restoration experiment tested the following treatments in a completely random design: (1) topsoil collected at the end of the dry season (spring, September 2012) (TS1): a 1-cm deep layer of topsoil was spread over each plot ( $5 \mathrm{~L} / \mathrm{plot})$; (2) topsoil collected at the end of the rainy season (summer, March 2013) (TS2): a 1-cm deep layer of topsoil was spread over each plot (5 L/plot); (3) hay collected at the end of the dry season (spring, September 2012) (H): a 5 -cm deep layer of hay was manually spread over each plot (25 L/plot); (4) topsoil + hay (TH): a 5-cm deep layer of hay was spread over a 1-cm layer of topsoil, both collected at the end of the dry season (spring, September 2012); and (5) control (C): no treatment applied after soil scrapping. We expected topsoil and hay transfers to bring diaspores and the hay to partly prevent soil desiccation and thus promote germination. We collected the soil at two different seasons as we expected the soil seed bank to be different depending on the season. The treatments with hay were not repeated at the end of the wet season, since hay inhibited germination in the plots installed in the end of dry season. To prevent the loss of hay with wind, the hay plots were covered with a $5 \mathrm{~cm}$ mesh net fixed to the ground with galvanized wire stakes, large enough to not obstruct light or to change microclimate. After a few days, the $5 \mathrm{~cm}$ of fresh hay layer was reduced to a thin and compact layer of dry material on the soil surface.

\section{Topsoil and Hay Collection}

Topsoil and hay were collected in a pristine cerrado grassland, without invasive species. Topsoil was collected twice in the same way: in September 2012 and in March 2013. Using a $25 \times 25 \mathrm{~cm}$ large $\times 5 \mathrm{~cm}$ deep mold (volume of $3.125 \mathrm{~L}$ ), we took 40 soil samples, totaling $125 \mathrm{~L}$ of topsoil for each season. The minimum distance between samples was $20 \mathrm{~m}$, to represent the spatial variation of the seed bank. Topsoil samples were mixed and homogenized prior to being spread on the experimental restoration plots.

Hay was collected only at the end of the dry season (September 2012), as phenological studies in the cerrado show a peak of seed dispersal at this time (Almeida 1995; Carmona et al. 1998; Munhoz \& Felfili 2005; Pilon et al. 2015). To collect the hay, we first cut the vegetation on a $50 \mathrm{~cm}$ wide strip with a grass trimmer (Stihl 160 F5, ANDREAS STIHL AG \& Co KG Waiblingen, Germany). About $0.3 \mathrm{~m}^{3}$ of fresh hay (not compacted) was then collected along that strip (three plastic bags of $100 \mathrm{~L}$ capacity), using a hand equipment normally used as leaf vacuum (TEKNA-SA260TKY, TEKNA FOREST \& GARDEN). The hay was then mixed and homogenized before being spread on the experimental restoration plots. Both topsoil and hay were collected in the reference ecosystem and spread on the plots the same day, to avoid possible dehydration of seeds.

\section{Vegetation Survey and Analyses}

We sampled all individuals in the plant community within the five plots of the reference ecosystem (September 2012, by the time of hay collection), as well as in the experimental plots (every 15 days during 211 days from the treatment application). The species were identified in the field whenever possible. Species whose identification was not possible in the field were collected for comparison to herbarium specimens and consulting experts. From these data, we obtained species richness (number of species/plot) and plant density (number of individuals $/ \mathrm{m}^{2}$ ) at the end of the 211 days observation period. For both richness and plant 
density, we included short-life cycle species, which germinated and died during the observation period. Considering that the aim of the restoration experiment was to reintroduce species from the reference ecosystem, we classified all encountered species according to their growth form (subshrubs or herbaceous species) and whether they were target species (species that occur in the reference ecosystem) or nontarget species (which may be ruderal or not, but which do not occur in the reference ecosystem), following Sano et al. (2008) and Flora do Brasil .

For each of the five treatments, total species richness, richness of target species, total plant density, and plant density of target species were assessed and compared using one-way analysis of variance (ANOVA). When the overall effect of treatment was significant $(p<0.05)$, we carried out a Tukey post hoc test to examine pairwise differences among treatments. In order to meet ANOVA assumptions, we log-transformed the richness and density data (and for species richness of target species, with use $\log (x+1))(\operatorname{Zar} 1999)$.

We compared the proportion of subshrubs and herbaceous species sampled in all restored plots with those of the reference ecosystem using a chi-square test of independence, using the Yates correction (Zar 1999).

To compare the composition and structure of communities resulting from restoration experiments with the reference ecosystem we used two indices: CSII ${ }_{\text {norm }}$ (normalized Community Structure Integrity Index) and HAI (Higher Abundance Index) (Jaunatre et al. 2013). We performed these analyses differentiating target and nontarget species.

Summarizing, the aim behind these indices is to characterize the species abundance in the community being restored as lower or higher in comparison to the reference ecosystem. This approach allows the assessment of the community under restoration by two components of

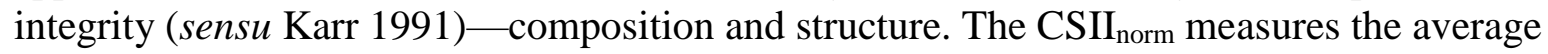
proportion of species' abundance in the reference ecosystem that is represented in the restored community. Therefore, this index focuses on the "deficit" of species abundance in the assessed community, ranging from 0 to 1 , where 1 represents all species with the same abundance in both communities. Values below 1 indicate that some species from the reference ecosystem are less abundant or absent in the restored ecosystem. HAI represents species occurring only in the restored ecosystems or in higher abundance than that observed in the reference ecosystem and also ranges from 0 to 1 (Jaunatre et al. 2013), where 1 corresponds to all species in the treatments with higher abundance than in the reference ecosystem. We compared the values obtained for these indices among treatments and with the reference community using ANOVA, followed by the Tukey post hoc test. All analyzes were performed using the R software (R Development Core Team 2014).

\section{Results}

\section{Species Richness and Plant Density}

Total species richness (target + nontarget species per plot) on plots with hay transfer $(\mathrm{H})$, was the lowest (only two species) among all restoration treatments, and also lower than control plots, with four species per plot $(F=24.81, p<0.001$; Fig. $1 \mathrm{~A})$. The highest values for species richness were recorded with topsoil transfer alone, with no difference between collection in summer (13 species per plot) or spring (10 species per plot). When we compared richness considering only target species, plots restored with summer topsoil transfer (12 species) provided better results than all other treatments $(F=49.36, p<0.001 ;$ Fig. 1B). Spring topsoil 
transfer resulted in five species per plot, followed by topsoil covered by hay (two species) and the lowest richness of target species was recorded with hay alone or in the control plots, both with a single species recovered per plot.

(A)

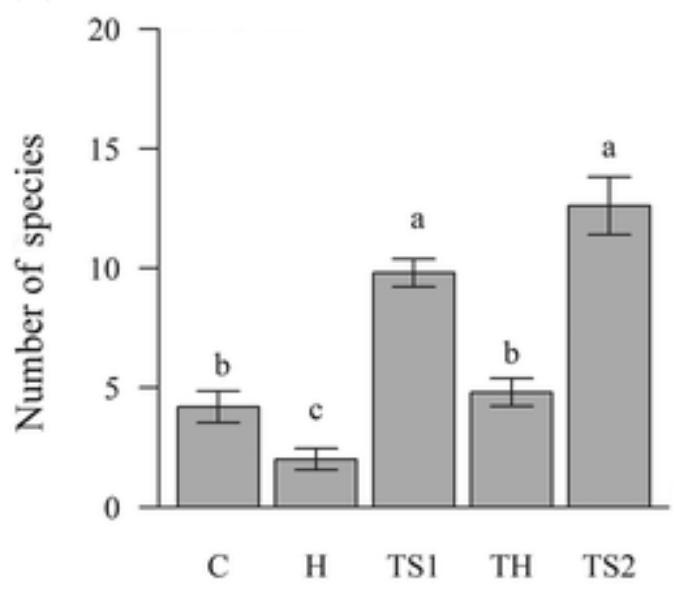

(B)

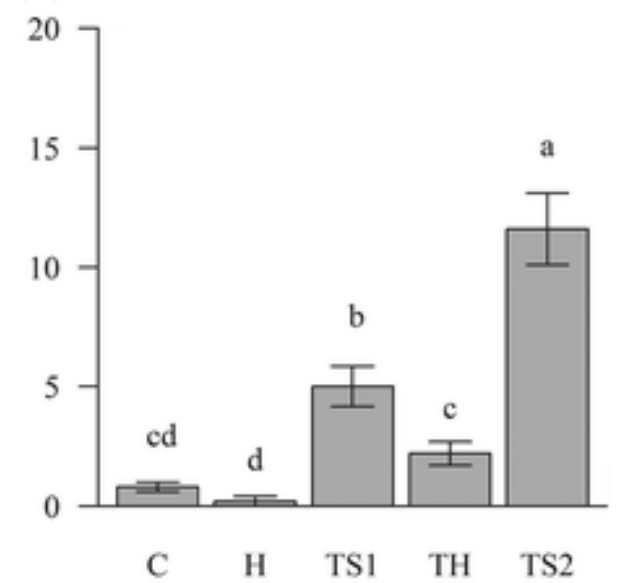

(D)

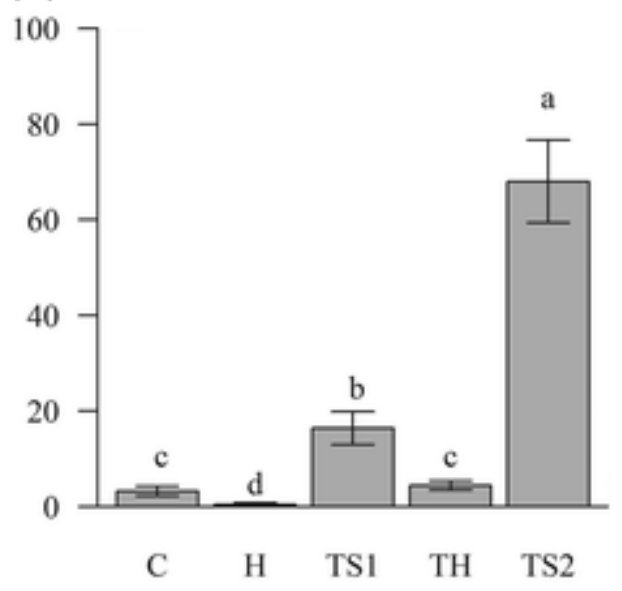

Figure 1

Species richness and plant densities on the various restoration treatments of cerrado grassland tested, at 211 days after treatments application. (A) Total species richness, (B) species richness of target species only (excluding nontarget species), (C) density of all plant, and (D) density of target plants (excluding nontarget species). Error bars represent $\pm \mathrm{SE}$, columns having a common letter are not significantly different (Tukey; $p>0.05)(\mathrm{C}$, control; $\mathrm{H}$, hay transfer; TSI, topsoil spring; TH, topsoil spring + hay; TS2, topsoil summer).

As observed for species richness, total plant density in the plots restored with topsoil transfer (70 ind. $/ \mathrm{m}^{2}$ in the summer topsoil and $36 \mathrm{ind} . / \mathrm{m}^{2}$ for spring topsoil) was higher than in other treatments $\left(24,14\right.$, and $10 \mathrm{ind} . / \mathrm{m}^{2}$ in control plots, topsoil + hay, and hay, respectively) and did not differ between seasons of topsoil collection (Fig. $1 \mathrm{C} ; F=8.01, p<0.001$ ). Total plant density in plots with hay transfer, with spring topsoil transfer, and with topsoil + hay transfer were not significantly different from that of control plots (Fig. 1C). When considering target species only, plant density in plots restored with summer topsoil transfer $\left(68 \mathrm{ind} . / \mathrm{m}^{2}\right)$ was higher than that obtained by any of the other treatments $(F=49.69, p<0.001)$. Among the other treatments, density of target species using spring topsoil $\left(16\right.$ ind. $\left./ \mathrm{m}^{2}\right)$ was higher than topsoil + hay, control plots, and hay (with 4,3 , and 1 ind. $/ \mathrm{m}^{2}$, respectively). Density resulting from hay transfer was even lower than in control plots. 


\section{Plant Community Composition}

Considering the species recorded in the plots of each treatment altogether, 11 species were recorded in the control plots (out of which 10 nontarget species), 7 in the plots with hay transfer (6 nontarget species), 13 in the plots with topsoil + hay (10 nontarget species), 24 in plots with spring topsoil transfer (9 nontarget species). Plots with summer topsoil transfer totaled 33 species recorded (6 nontarget species) (Table S1, Supporting Information).

The proportions of herbaceous species and subshrubs differed between restored and reference ecosystem $\left(\chi^{2}=16.92, p<0.001\right)$. In the reference ecosystem, $40 \%$ of the species were subshrubs and $60 \%$ were herbaceous. In the whole experimental area (restoration treatments), herbaceous species represented $90 \%$ of the total number of species sampled (Fig. 2).

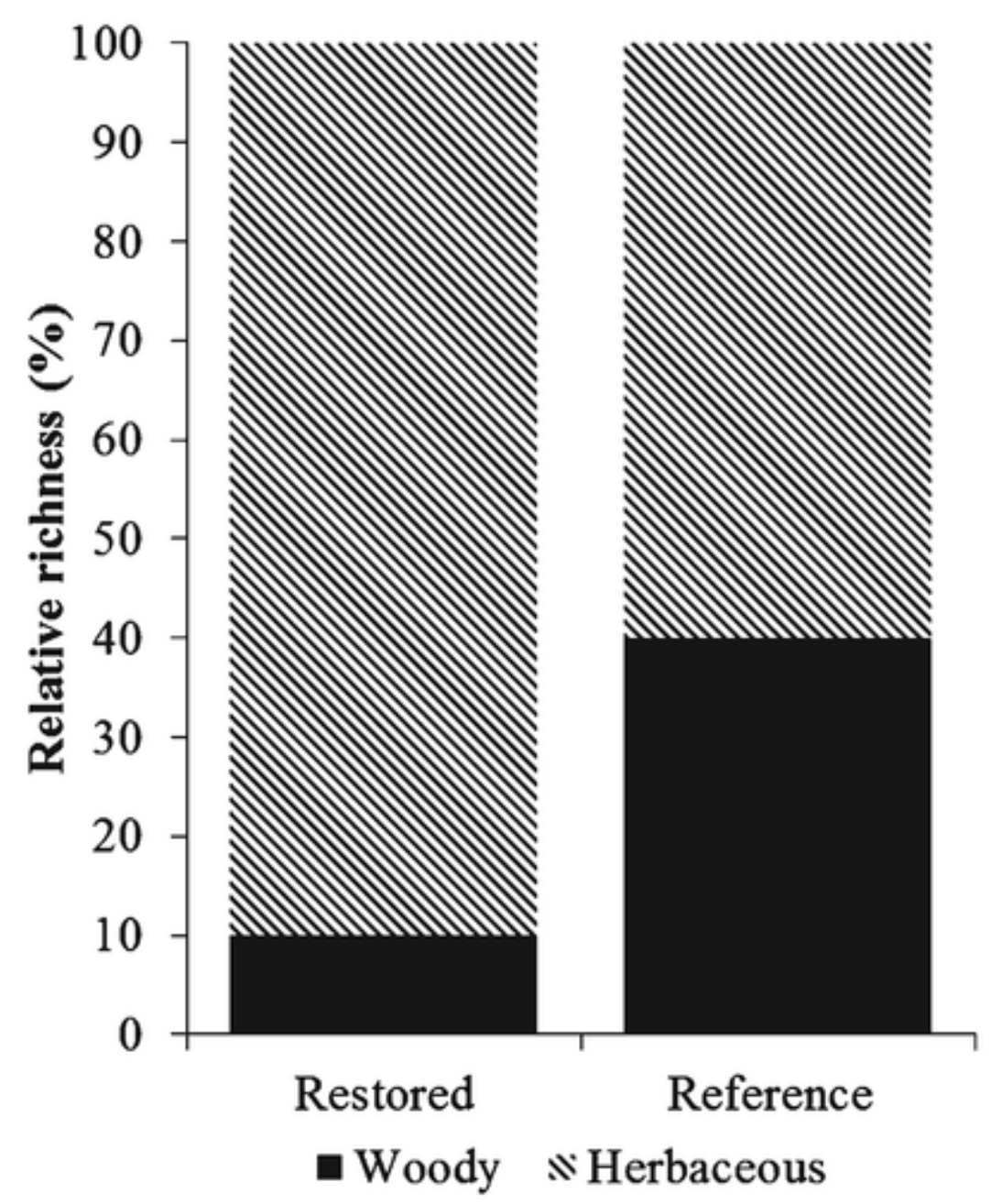

Figure 2

Proportions of herbaceous and subshrubs sampled in all plots of the experimental area and in the reference ecosystem over the period of observations. Proportions of herbaceous and subshrubs in the restoration experiment differ from the expected on the basis of the reference ecosystem $\left(\chi^{2}=16.92, p<0.001\right)$.

The highest values of $\mathrm{CSII}_{\text {norm }}$ for treatments were obtained for topsoil transfer if collected in the summer, followed by the same technique when topsoil is collected in the spring, both superior to the other treatments (Fig. $\underline{3} \mathrm{~A} ; F=77.16, p<0.001$ ). However, CSII ${ }_{\text {norm }}$ was below 0.4 in all restoration treatments, indicating that none of the techniques recovered more than 
$40 \%$ of the species composition and abundance of the old-growth grassland used as reference. Additionally, by the HAI, no difference was found among treatments, while all techniques differed from the reference (Fig. $\underline{3} \mathrm{~B} ; F=8.25, p<0.001$ ). A high proportion of nontarget species brought by the restoration techniques (e.g. Phyllanthus tenellus and Sida glaziovii) were not sampled in the reference ecosystem. Some target species were more abundant in the restoration treatments than in the reference ecosystem (e.g. Axonopus pressus and Bulbostylis hirtella) and some were not recorded in any of the restoration treatments (Fig. $\underline{4}$ ).
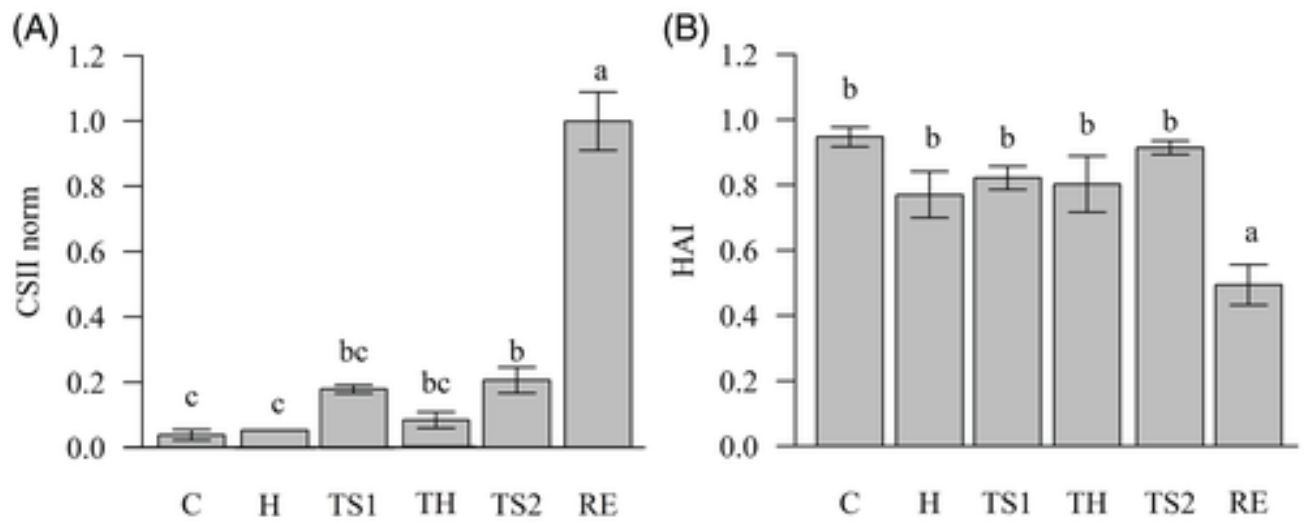

Figure 3

Analysis of species composition and abundance in comparison to the reference ecosystem two indices: (A) CSII norm and (B) HAI. Error bars represent \pm SE, columns having a common letter are not significantly different (Tukey; $p>0.05)(\mathrm{C}$, control; $\mathrm{H}$, hay transfer; TSI, topsoil spring; TH, topsoil spring + hay; TS2, topsoil summer; RE, reference ecosystem).

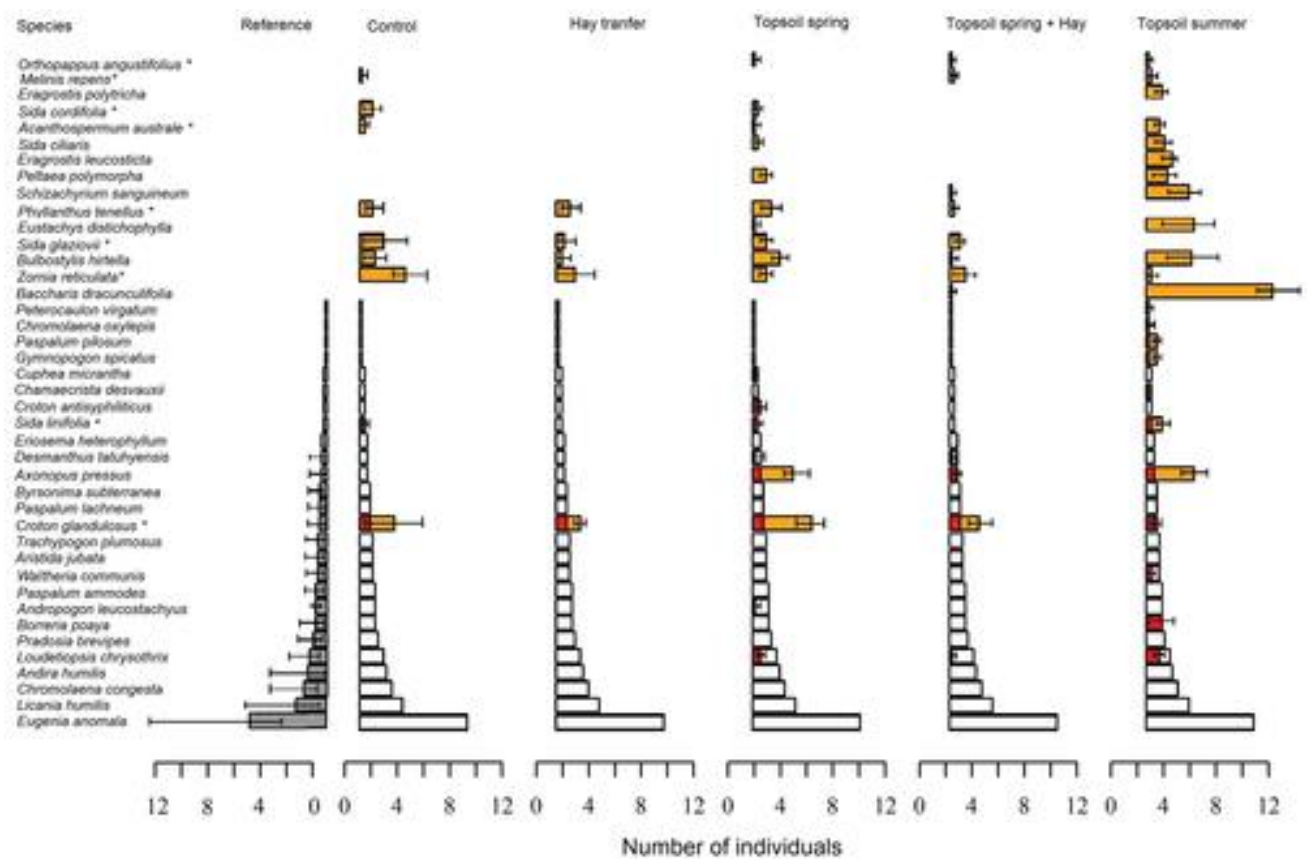

Figure 4

Mean abundances of the species in the reference ecosystem and restoration treatments. Gray columns represent mean abundances in the reference ecosystem. White columns represent missing abundances in the restoration treatments, red columns represent mean abundances in the restoration treatments up to the mean abundances in the reference ecosystem and orange columns represent abundances which are higher than in the reference ecosystem. Only species which occur in more than three samples are shown. Error bars represent \pm SE. * indicate nontarget species. 
Detailed information on all ANOVA results (degrees of freedom, sum of squares, mean of squares, $F$ value, and $p$-value) for richness, density, or species composition are presented in Table S2.

\section{Discussion}

The woody cerrado vegetation (trees, shrubs, and subshrubs) has been reported to be highly resilient to disturbances, naturally recovering after decades of land uses such as pasture or silviculture (Coutinho 1990; Durigan et al. 1997, 1998). The herbaceous layer, however, does not recover spontaneously, and the ground is often colonized by exotic grasses, resulting in novel ecosystems (invaded cerrado vegetation was used as an example by Hobbs et al. 2006). This vegetation formed by a tree layer composed by native trees spread over invasive grasses can be similar to the historical vegetation in providing some ecosystem services such as carbon sequestration or water protection. However, it lacks plant species composition indicative of undisturbed cerrado and thus does not provide suitable habitat for some specialized fauna, likely changing also the fire regime. Recovering the herbaceous component of cerrado vegetation therefore remains a challenge even for the huge areas where natural regeneration of woody plants is possible. In this study we conducted experiments with different techniques to restore the cerrado grasslands. The results show some failures, but also some promising techniques in terms of their efficacy in recovering the richness, the structure and species composition of reference grasslands.

\section{Species Richness and Plant Density}

Although hay transfer was successful to restore plant communities of grasslands in other regions of the world (Hölzel \& Otte 2003; Kiehl \& Wagner 2006; Kiehl et al. 2010; CoiffaitGombault et al. 2011), the results obtained here prove that this technique is not always efficient in cerrado grasslands. The hay collected in this study apparently was not a sufficient source of propagules to be used in a restoration program, as shown in other types of tropical grasslands, such as campos rupestres (Le Stradic et al. 2014). Moreover, many species of the cerrado are heliophilous (Coutinho 1978) and thus require light for germination and establishment. In this study, the hay probably hampered germination, shading the ground, and limiting germination of herbaceous species. The application of this restoration technique thus led to even less germination than in the control, where no restoration treatment was applied.

On the other hand, topsoil transfer showed to be a promising technique in terms of richness and density of target species. The timing of topsoil transfer was shown to be very important, as we obtained better results when transferring the soil in summer, at the end of the rainy season. The difference in the outcomes of topsoil transfer among seasons can be explained by the phenology of the species, since most herbaceous plants of the cerrado disperse their seeds is the period between March and June (Almeida 1995; Carmona et al. 1998; Munhoz \& Felfili 2005), corresponding to the end of the summer. Additionally, this experiment suggested that, as demonstrated for woody cerrado species (Salazar et al. 2011), a large part of the seed bank is not persistent, likely not surviving the dry season.

\section{Plant Community Composition}

The high proportion of herbaceous species recorded in the 25 restoration plots (only 5 subshrubs out of 46 species total) compared with that of the 5 plots of the reference ecosystem 
(14 subshrubs for 35 species total) shows that a reasonable proportion of the herbaceous plants can be recovered especially by topsoil transfer, but subshrubs were generally missed in our study. On the other hand, Ferreira et al. (2015), also restoring the cerrado vegetation by topsoil transfer, obtained a high number of woody species. The contrasting results are likely related to the depth of the topsoil layer extracted. While this layer was only $5 \mathrm{~cm}$ deep in our study, aiming to preserve the underground structures and thus the resilience of the donor site (Pilon 2016), those authors extracted a much thicker layer, $40 \mathrm{~cm}$ deep (since the donor site was going to be urbanized). Extracting a deep soil layer allows transferring underground organs with resprouting capacity. There is, however, a clear trade-off between quality of the top soil (amount of viable propagules) and resilience of the donor site. Several studies have shown a high potential of resprouting of the woody cerrado plants even after long periods of disturbance (Coutinho 1990; Durigan et al. 1998), if underground organs are preserved. Other depths for topsoil extraction should be tested, as well as other techniques, such as seedling transplantation or vegetative propagation using roots, in order to recover subshrubs. These techniques have been recommended as complementary interventions to reintroduce subshrubs with large root systems when restoring cerrado grasslands (Filgueiras 2002). The vegetative propagation of shrub and subshrub cerrado species, however, has been poorly studied (see Vieira et al. 2013). The well developed capacity of cerrado woody plants to resprout in natural areas (Coutinho 1990), however, did not result in subshrubs colonizing our experimental plots. Apparently, root fragments extracted with surface topsoil do not resprout as well in areas to be restored as in natural ecosystems after disturbance. Ferreira et al. (2015) managed to establish some shrub and subshrub target species through deeper topsoil transfer, as discussed above; however, many transplanted individuals were unable to establish themselves in the area under restoration (from initial 3.2 to $0.5 \mathrm{stem} / \mathrm{m}^{2}$ after 37 months). The techniques of transplanting underground organs need additional studies.

For the small experimental area, finding 27 target species coming from the summer topsoil is a surprising result in terms of plant diversity recovery (Table S1). Composition and structure of the community resulting from these techniques, however, are very different from the reference old-growth grassland, with several shrub and subshrub species absent and nontarget corresponding to the major proportion of plants in the community being restored. Topsoil transfer can be considered, meanwhile, a promising technique to at least rehabilitate degraded areas and provide opportunities for more research about restoration of tropical grasslands. If this technique was going to be used at large scale, obtaining enough topsoil material to transfer could be a limiting factor. Remnant areas of cerrado grasslands are scarce and are rarely free of invasive African grasses (Pivello et al. 1999; Durigan et al. 2007). The collection of great quantities of topsoil thus could be extremely detrimental to the few areas of cerrado grasslands that remain. Furthermore, if source areas have been colonized by invasive African grasses, topsoil transfer could lead to a disastrous result for the area to be restored. Right now, topsoil transfer is only applicable at small scale. For instance, it should be applied inside conservation units where undisturbed areas of cerrado grasslands can be source of topsoil to restore degraded areas in the same unit. In such cases, recovery of the donor sites should also be monitored. It can be also viable when the destruction of a well conserved (and not invaded) ecosystem has been planned and approved and will have its topsoil discarded, such as mining sites, urban areas, and hydroelectrical dams. The material from these sites could be extracted to restore degraded areas elsewhere. In the best case scenario, in which demand for cerrado grassland restoration is great, recovering topsoil rich in native cerrado species may even constitute a business opportunity to complement nurseries that currently just provide seedlings of tree species. 
Although the community composition resulting from topsoil transfer is still very different from that of the reference ecosystem, topsoil transfer proved to be an important step in the restoration of degraded tropical grasslands. This first step must be followed by other ones, to give support to grasslands restoration at large scale. Our experiment was conducted on a small scale, under controlled conditions. After the period of observations for this study, plots from all treatments were invaded by African grasses, showing that restoration success can be reverted if the invasion is not controlled and managed, as previously observed by Ferreira et al. (2015). The techniques tested in our study should ideally be experimented in larger areas. Additionally, attention must be paid to possible edge effects, invasive species management, and costs of restoration techniques must be incorporated into the evaluation of restoration success. The limitations of the techniques tested to reintroduce all functional types of plants (particularly resprouters) that compose cerrado grasslands highlight the need for conserving the remaining old-growth cerrado grasslands.

\section{Acknowledgments}

We thank J.S. Brewer, two anonymous reviewers, and the editors for valuable comments on the previous version of the manuscript. N.A.L.P. thanks Fundação de Amparo à Pesquisa do Estado de São Paulo-FAPESP, by scholarship grant (\#2012/09048-3) and G.D. thanks the Conselho Nacional de Desenvolvimento Científico e Tecnológico- $\mathrm{CNPq}$, by the productivity grant (\#303402/2012-1).

\section{LITERATURE CITED}

- Almeida, SP ( 1995) Grupos fenológicos da comunidade de gramíneas perenes de um campo cerrado no Distrito Federal, Brasil. Pesquisa Agropecuária Brasileira 30: $1067-1073$

\section{$\underline{\text { Google Scholar }}$}

- Alvares, CA, Stape, JL, Sentelhas, PC, Moraes, G, Leonardo, J, Sparovek, G ( 2013) Köppen's climate classification map for Brazil. Meteorologische Zeitschrift 22: 711728

\section{$\underline{\text { Google Scholar }}$}

- Bossuyt, B, Hermy, M ( 2003) The potential of soil seedbanks in the ecological restoration of grassland and heathland communities. Belgian Journal of Botany 136: $23-34$

\section{$\underline{\text { Google Scholar }}$}

- Burmeier, S, Eckstein, RL, Donath, TW, Otte, A ( 2011) Plant pattern development during early post-restoration succession in grassland - a case study of Arabis nemorensis. Restoration Ecology 19: 648- 659

\section{$\underline{\text { Google Scholar }}$}


- Carmona, R, Martins, CR, Fávero, AP ( 1998) Fatores que afetam a germinação de sementes de gramíneas nativas do cerrado. Revista Brasileira de Sementes 20: 16- 22

\section{$\underline{\text { Google Scholar }}$}

- Coiffait-Gombault, C, Buisson, E, Dutoit, T ( 2011) Hay transfer promotes establishment of Mediterranean stepp vegetation on soil disturbed by pipeline construction. Restoration Ecology 19: 214- 222

\section{$\underline{\text { Google Scholar }}$}

- Coiffait-Gombault, C, Buisson, E, Dutoit, T ( 2012) Using a two-phase sowing approach in restoration: sowing foundation species to restore, and subordinate species to evaluate restoration success. Applied Vegetation Science 15: 277- 289

\section{$\underline{\text { Google Scholar }}$}

- Corrêa, RS, Mélo Filho, BD, Pinheiro, CDQ, Santos, PF ( 2015) Floristic woody composition of revegetated mining sites in the Brazilian Federal District. Bioscience Journal 31: 908-922

\section{$\underline{\text { Google Scholar }}$}

- Coutinho, LM ( 1978) O conceito de Cerrado (The concept of Cerrado). Revista Brasileira de Botânica 1: 17-23

\section{$\underline{\text { Google Scholar }}$}

- Coutinho, LM ( 1990) Fire in the ecology of the Brazilian cerrado. Pages 82-105. In: JG Goldammer (ed) Fire in the tropical biota. Springer-Verlag, Berlin, Germany

\section{$\underline{\text { Google Scholar }}$}

- Durigan, G ( 2003) Bases e Diretrizes para a restauração da vegetação de Cerrado. Pages 187-201. In: PY Kageyama, RE Oliveira, LFD Moraes, VL Engel, FB Gandara (eds) Restauração ecológica de ecossistemas naturais. FEPAF, Botucatu, Brazil

\section{$\underline{\text { Google Scholar }}$}

- Durigan, G, Engel, VL ( 2012) Restauração de ecossistemas no Brasil: onde estamos e para onde podemos ir? Pages 41- 68. In: SV Martins (ed) Restauração ecológica de ecossistemas degradados. UFV, Viçosa, Brazil

\section{$\underline{\text { Google Scholar }}$}

- Durigan, G, Franco, GADC, Pastore, JA, Aguiar, OT ( 1997) Regeneração natural da vegetação de cerrado sob floresta de Eucalyptus citriodora. Revista do Instituto Florestal 9: 19- 36

\section{Google Scholar}


- Durigan, G, Contieri, WA, Franco, GADC, Garrido, MAO ( 1998) Indução do processo de regeneração da vegetação de cerrado em área de pastagem, Assis, SP. Acta Botanica Brasilica 12: 421- 429

\section{$\underline{\text { Google Scholar }}$}

- Durigan, G, Melo, ACG, Max, JCM, Honda, EA, Souza, MBM, Bôas, OV, Contiéri, WA ( 2010) Plano de Manejo da Estação Ecológica de Assis. Instituto Florestal, São Paulo, Brazil. www.iflorestal.sp.gov.br/Plano_de_manejo/eec_santa_barbara/Plano_de_Manejo_EEc _Santa_Barbara.pdf (accessed 26 Apr 2012)

\section{$\underline{\text { Google Scholar }}$}

- Ferreira, MC, Walter, BMT, Vieira, DLM ( 2015) Topsoil translocation for Brazilian savanna restoration: propagation of herbs, shrubs, and trees. Restoration Ecology 23: $723-728$

\section{$\underline{\text { Google Scholar }}$}

- Filgueiras, TS ( 2002) Herbaceous plant communities. Pages 121-139. In: PS Oliveira, JR Marquis (eds) The Cerrados of Brazil: ecology and natural history of a neotropical. Columbia University Press, New York

\section{$\underline{\text { Google Scholar }}$}

- Flora do Brasil 2020 em construção. Jardim Botânico do Rio de Janeiro. http://floradobrasil.jbrj.gov.br (accessed 17 Jan 2017)

\section{$\underline{\text { Google Scholar }}$}

- Harrington, JA, Kathol, E ( 2009) Responses of shrub midstory and herbaceous layers to managed grazing and fire in a North American savanna (oak woodland) and prairie landscape. Restoration Ecology 17: 234- 244

\section{$\underline{\text { Google Scholar }}$}

- Hobbs, RJ, Arico, S, Aronson, J, Baron, JS, Bridgewater, P, Cramer, VA, et al. ( 2006) Novel ecosystems: theoretical and management aspects of the new ecological world order. Global Ecology and Biogeography 15: 1- 7

\section{$\underline{\text { Google Scholar }}$}

- Hölzel, N, Otte, A ( 2003) Restoration of a species-rich flood meadow by topsoil removal and diaspore transfer with plant material. Applied Vegetation Science 6: 131140

\section{$\underline{\text { Google Scholar }}$}


- Jaunatre, R, Buisson, E, Dutoit, T ( 2012) First-year results of a multi-treatment steppe restoration experiment in La Crau (Provence, France). Plant Ecology and Evolution 145: $13-23$

\section{Google Scholar}

- Jaunatre, R, Buisson, E, Muller, I, Morlon, H, Mesléard, F, Dutoit, T ( 2013) New synthetic indicators to assess community resilience and restoration success. Ecological Indicators 29: 468-477

\section{$\underline{\text { Google Scholar }}$}

- Kageyama, PY, Gandara, FB ( 2000) Recuperação de Áreas Ciliares. Pages 249-270. In: RR Rodrigues, HF Leitão-Filho (eds) Matas ciliares: conservação e recuperação. Editora Universidade de São Paulo/FAPESP, São Paulo, Brazil

\section{$\underline{\text { Google Scholar }}$}

- Kiehl, K ( 2010) Plant species introduction in ecological restoration: possibilities and limitations. Basic and Applied Ecology 11: 281- 284

\section{$\underline{\text { Google Scholar }}$}

- Kiehl, K, Pfadenhauer, J ( 2007) Establishment and persistence of target species in newly created calcareous grassland on former arable fields. Plant Ecology 189: 31- 48

\section{$\underline{\text { Google Scholar }}$}

- Kiehl, K, Wagner, C ( 2006) Effect of hay transfer on long-term establishment of vegetation and grasshoppers on former arable fields. Restoration Ecology 14: 157166

\section{$\underline{\text { Google Scholar }}$}

- Kiehl, K, Kirmer, A, Donath, TW, Rasran, L, Hölzel, N ( 2010) Species introduction in restoration projects - evaluation of different techniques for the establishment of semi-natural grassland in Central and Northwestern Europe. Basic and Applied Ecology 11: 285- 299

\section{$\underline{\text { Google Scholar }}$}

- Klimkowska, A, Kotowski, W, Van Diggelen, R, Grootjans, AP, Dzierza, P, Brzezínska, K ( 2010) Vegetation re-development after fen meadow restoration by top soil removal and hay transfer. Restoration Ecology 18: 924- 933

\section{$\underline{\text { Google Scholar }}$}

- Klink, C, Machado, RB ( 2005) Conservation of the Brazilian Cerrado. Conservation Biology 19: 707-713 


\section{$\underline{\text { Google Scholar }}$}

- Le Stradic, S, Buisson, E, Negreiros, P, Campagne, P, Fernandes, GW ( 2014) The role of native woody species in the restoration of Campos rupestres in quarries. Applied Vegetation Science 17: 109- 120

\section{$\underline{\text { Google Scholar }}$}

- Le Stradic, S, Séleck, M, Lebrun, J, Boisson, S, Handjila, G, Faucon, MP, Enk, T, Mahy, G ( 2015) Comparison of translocation methods to conserve metallophyte communities in the Katangan Copperbelt, DRC. Environmental Science and Pollution Research 23: 13681- 13692

\section{$\underline{\text { Google Scholar }}$}

- Maloney, JN ( 1997) Oak Savanna Restoration Techniques. Restoration and Reclamation Review 2: 1-7

\section{$\underline{\text { Google Scholar }}$}

- Melo, AC, Durigan, G ( 2011) Plano de manejo da estação ecológica de Santa Bárbara. Instituto Florestal, São Paulo, Brazil. http://www.iflorestal.sp.gov.br/Plano_de_manejo/eec_santa_barbara/Plano_de_Manej o_EEc_Santa_Barbara.pdf (accessed 26 Apr 2012)

\section{Google Scholar}

- Munhoz, CBR, Felfili, JM ( 2005) Fenologia do estrato herbáceo-subarbustivo de uma comunidade de campo sujo na Fazenda Água Limpa no Distrito Federal, Brasil. Acta Botanica Brasilica 19: 979-988

\section{$\underline{\text { Google Scholar }}$}

- Pilon, NAL ( 2016) Técnicas de restauração de fisionomias campestres do cerrado e fatores ecológicos atuantes. Master dissertation. Universidade Estadual de Campinas, Campinas, Brazil

\section{$\underline{\text { Google Scholar }}$}

- Pilon, NAL, Durigan, G ( 2013) Critérios para indicação de espécies prioritáriaspara a restauração da vegetação de cerrado. Scientia Forestalis 41: 389- 399

\section{$\underline{\text { Google Scholar }}$}

- Pilon, NAL, Udulutsch, RG, Durigan, G ( 2015) Padrões fenológicos de 111 espécies de Cerrado em condições de cultivo. Hoehnea 42: 425- 444

\section{$\underline{\text { Google Scholar }}$}


- Pivello, VR, Shida, CN, Meirelles, ST ( 1999) Alien grasses in Brazilian savannas: a threat to the biodiversity. Biodiversity \& Conservation 8: 1281- 1294

\section{$\underline{\text { Google Scholar }}$}

- R Development Core Team ( 2014) R: a language and environment for statistical computing. R Foundation for Statistical Computing, Vienna, Austria. http://www.Rproject.org/

\section{$\underline{\text { Google Scholar }}$}

- Rasran, L, Vogt, K, Jensen, K ( 2007) Effects of topsoil removal, seed transfer with plant material e moderate grazing on restoration of riparian fen grasslands. Applied Vegetation Science 10: 451- 46

\section{$\underline{\text { Google Scholar }}$}

- Ribeiro, JF, Walter, BMT ( 2008) As principais fitofisionomias do bioma cerrado. Pages 151- 199. In: SM Sano, SP Almeida, JF Ribeiro (eds) Cerrado: ecologia e flora. Embrapa, Brasília, Brazil

\section{$\underline{\text { Google Scholar }}$}

- $\quad$ Rodrigues, RR, Lima, RAF, Gandolfi, S, Nave, AG ( 2009) On the restoration of high diversity forests: 30 years of experience in the Brazilian Atlantic Forest. Biological Conservation 142: 1242- 1255

\section{$\underline{\text { Google Scholar }}$}

- Salazar, A, Goldstein, G, Franco, AC, Miralles-Wilhelm, F ( 2011) Timing of seed dispersal and dormancy, rather than persistent soil seed-banks, control seedling recruitment of woody plants in Neotropical savannas. Seed Science Research 21: 103116

\section{Google Scholar}

- Sano, SM, Almeida, SP, Ribeiro, JF ( 2008) Cerrado: ecologia e flora. Vol 2. Embrapa Cerrados, Brasília, Brazil

\section{$\underline{\text { Google Scholar }}$}

- Van Lear, DH, Carroll, WD, Kapeluck, PR, Johnson, R ( 2005) History and restoration of the longleaf pine-grassland ecosystem: implications for species at risk. Forest Ecology and Management 211: 150- 165

\section{$\underline{\text { Google Scholar }}$}

- Vécrin, MP, Muller, S ( 2003) Topsoil translocation as a technique in the re-creation of species-rich meadows. Applied Vegetation Science 6: 271- 278 


\section{$\underline{\text { Google Scholar }}$}

- Veldman, JW, Buisson, E, Durigan, G, Fernandes, GW, Le Stradic, S, Mahy, G, et al. ( 2015a) Toward an old-growth concept for grasslands, savannas, and woodlands. Frontiers in Ecology and the Environment 13: 154- 162

\section{$\underline{\text { Google Scholar }}$}

- Veldman, JW, Overbeck, GE, Negreiros, D, Mahy, G, Le Stradic, S, Fernandes, GW, Durgian, G, Buisson, E, Putz, FE, Bond, WJ ( 2015b) Where tree planting and forest expansion are bad for biodiversity and ecosystem services. BioScience 65: 1011- 1018

\section{$\underline{\text { Google Scholar }}$}

- Veldman, JW, Overbeck, GE, Negreiros, D, Mahy, G, Le Stradic, S, Fernandes, GW, Durigan, G, Buisson, E, Putz, FE, Bond, WJ ( 2015c) Tyranny of trees in grassy biomes. Science 347: 484- 485

\section{$\underline{\text { Google Scholar }}$}

- Vieira, DL, Coutinho, AG, Rocha, GP ( 2013) Resprouting ability of dry forest tree species after disturbance does not relate to propagation possibility by stem and root cuttings. Restoration Ecology 21: 305- 311

\section{$\underline{\text { Google Scholar }}$}

- Walker, JL, Silletti, AM ( 2006) Restoring the ground layer of longleaf pine ecosystems. Pages 297- 333. In: S Jose, EJ Jokela, DL Miller (eds) The longleaf pine ecosystem. Springer, New York

\section{$\underline{\text { Google Scholar }}$}

- Zar, JH ( 1999) Biostatistical analysis. Prentice-Hall, Upper Saddle River, New Jersey

\section{$\underline{\text { Google Scholar }}$}

